\title{
Spring Nitrogen Uptake, Use Efficiency, and Partitioning for Growth in Iris germanica 'Immortality'
}

\author{
Xiaojie Zhao, Guihong Bi ${ }^{1}$, Richard L. Harkess, and Jac J. Varco \\ Department of Plant and Soil Sciences, Mississippi State University, Mississippi \\ State, MS 39762
}

\author{
Eugene K. Blythe \\ Coastal Research and Extension Center, Mississippi State University, South \\ Mississippi Branch Experiment Station, Poplarville, MS 39470
}

Additional index words. tall bearded iris, ${ }^{15} \mathrm{~N}$, uptake efficiency, $\mathrm{C} / \mathrm{N}$ ratio

\begin{abstract}
This study investigated how spring nitrogen $(\mathrm{N})$ application affects $\mathrm{N}$ uptake and growth performance in tall bearded (TB) iris 'Immortality' (Iris germanica L.). Container-grown iris plants were treated with $0,5,10,15$, or $20 \mathrm{~mm} \mathrm{~N}$ from ${ }^{15} \mathrm{NH}_{4}{ }^{15} \mathrm{NO}_{3}$ through fertigation using a modified Hoagland's solution twice a week for 6 weeks in Spring 2013. Increasing $N$ rate increased plant height, total plant dry weight $(D W)$, and $N$ content. Total $\mathbf{N}$ content was closely related to total plant DW. The allocation of $N$ to different tissues followed a similar trend as the allocation of DW. In leaves, roots, and rhizomes, increasing $\mathrm{N}$ rate increased $\mathrm{N}$ uptake and decreased carbon $(\mathrm{C})$ to $\mathrm{N}$ ratio $(\mathrm{C} / \mathrm{N}$ ratio). Leaves were the major sink for $\mathrm{N}$ derived from fertilizer (NDFF). As $\mathrm{N}$ supply increased, DW accumulation in leaves increased, whereas DW accumulation in roots and rhizomes was unchanged. This indicates increasing $\mathbf{N}$ rate contributed more to leaf growth in spring. Nitrogen uptake efficiency (NupE) had a quadratic relationship with increasing $N$ rate and was highest in the $10 \mathrm{~mm} N$ treatment, which indicates $10 \mathrm{~mm}$ was the optimal $\mathrm{N}$ rate for improving $\mathrm{NupE}$ in this study.
\end{abstract}

TB iris (Iris germanica) is a perennial plant belonging to the family Iridaceae. Hundreds of TB iris hybrids exist representing every color from jet black to sparkling white. TB iris is a popular garden plant with potential as a cut-flower crop. In spring, TB iris produces great amounts of shoot growth, which requires sufficient nutrient supply from both internal and external sources. Usually, fertilization in early spring and after spring flowering is recommended for growing TB iris (Lockatell and Spoon, 2011). However, limited information is available regarding how $\mathrm{N}$ rate affects spring $\mathrm{N}$ uptake and use efficiency in TB iris.

Nitrogen plays an important role in plant growth and development. Insufficient N supply restricts plant growth. Increasing $\mathrm{N}$ application rate influences plant growth $(\mathrm{Bi}$ et al., 2007), leaf $\mathrm{CO}_{2}$ assimilation (Cheng

\footnotetext{
Received for publication 29 Dec. 2015. Accepted for publication 8 Mar. 2016.

Contribution of the Mississippi Agricultural and Forestry Experiment Station Journal article no. 12746. This work was supported by the Mississippi Agriculture and Forestry Experiment Station, the USDA National Institute of Food and Agriculture Hatch projects MIS-249120 and MIS-212050, and the China Scholarship Council.

Mention of a trademark, proprietary product, or vendor does not constitute a guarantee or warranty of the product by Mississippi State University and does not imply its approval to the exclusion of other products or vendors that also may be suitable.

${ }^{1}$ Corresponding author. E-mail: gbi@pss.msstate.edu.
}

and Xia, 2004), and uptake and allocation of other nutrients (Scagel et al., 2008, 2012). However, excessive $\mathrm{N}$ fertilizer application results in higher root zone electrical conductivity, which causes lower gas exchange rates, shoot DW, and SPAD readings (Niu et al., 2011). Increasing $\mathrm{N}$ supply may decrease NupE and lead to more $\mathrm{N}$ runoff to the environment (Syvertsen and Smith, 1996). Understanding a plant's $\mathrm{N}$ requirement and the way $\mathrm{N}$ affects production and quality of plants is important to both the environment and crop production (Bi et al., 2008; Dong et al., 2004; Lea-Cox et al., 2001; Scagel et al., 2012).

Nitrogen use efficiency (NUE) is estimated as the amount of dry matter fixed in plant biomass per unit of $\mathrm{N}$ applied (Marschner, 2012), which integrates two components: plant NupE and use efficiency of absorbed $\mathrm{N}\left(\mathrm{N}_{\mathrm{a}} \mathrm{UE}\right)$ by the plant (Benincasa et al., 2011). NupE is the ability of the plant to take up $\mathrm{N}$ from supplied fertilizer. $\mathrm{N}_{\mathrm{a}} \mathrm{UE}$ demonstrates the ability of the plant to use the absorbed $\mathrm{N}$ to produce dry biomass. Considering mean residence time of $\mathrm{N}$ in plant tissue affected NUE responses to increasing $\mathrm{N}$ availability, NupE showed a more dynamic response to $\mathrm{N}$ availability from applied $\mathrm{N}$ (Iversen et al., 2010).

$\mathrm{C} / \mathrm{N}$ ratio of biomass may indicate relative availability of $\mathrm{C}$ and $\mathrm{N}$ sources (Herms and Mattson, 1992). Carbon constitutes $\approx 50 \%$ of plant DW and provides the structural basis for plants (Agren, 2008) and C compounds provide both energy and the $\mathrm{C}$ skeletons for amino acid assimilation. If $\mathrm{C}$ supply is insufficient, it will cause decreased $\mathrm{N}$ uptake and assimilation (Zhang, 2009). On the other hand, insufficient $\mathrm{N}$ supply reduces photosynthetic output, such as, sucrose and glucose (Coruzzi and Zhou, 2001). By controlling N application, $\mathrm{C} / \mathrm{N}$ ratios can be adjusted in crops to enhance yield and quality.

The objectives of this study were to investigate influences of $\mathrm{N}$ rate on plant growth, $\mathrm{N}$ concentration, content, allocation, and $\mathrm{C} / \mathrm{N}$ ratio, and to evaluate the effects of increasing $\mathrm{N}$ rate on $\mathrm{N}$ uptake, NUE, NupE, and $\mathrm{N}_{\mathrm{a}} \mathrm{UE}$ during the spring growth period.

\section{Materials and Methods}

This study was conducted under natural conditions in Starkville, MS (lat. $33^{\circ} 27^{\prime} \mathrm{N}$, long. $88^{\circ} 47^{\prime}$ W). In Aug. 2012, rhizomes (average caliper $=4.7 \mathrm{~cm}$ and length $=5.8 \mathrm{~cm}$ ) of TB iris 'Immortality' (Schreiner's Iris Gardens, Salem, OR) were potted one rhizome per pot into $3.78-\mathrm{L}(23 \mathrm{~cm}$ diameter; $16 \mathrm{~cm}$ height) round plastic pots filled with commercial substrate with no starter fertilizer (Fafard growing mix 2; Sun Gro Horticulture, Agawam, MA). Fertigation was applied to plants twice per week from 28 Aug. to 28 Sept. in 2012 with plants receiving $400 \mathrm{~mL}$ of modified Hoagland's solution (Hoagland and Arnon, 1950) containing $10 \mathrm{~mm} \mathrm{~N}$ from $\mathrm{NH}_{4} \mathrm{NO}_{3}$ to provide basic nutrient supply for fall growth.

On 25 Mar. 2013, before the start of spring $\mathrm{N}$ treatments, five plants were harvested for background biomass and nutrient composition. Remaining plants were fertigated twice per week from 25 Mar. to 3 May 2013 with $250 \mathrm{~mL}$ of modified Hoagland's solution containing one of five $\mathrm{N}$ concentrations $(0,5,10,15$, or $20 \mathrm{~mm} \mathrm{~N})$ from ${ }^{15} \mathrm{NH}_{4}{ }^{15} \mathrm{NO}_{3}$. The monthly average air temperature was $11.6,17.7$, and $21.9^{\circ} \mathrm{C}$ in Mar., Apr., and May 2013, respectively. The experiment was arranged as a randomized complete block design with five blocks. In each block, four plants in one group was an experimental unit receiving one of five $\mathrm{N}$ rates. Five plants from each $\mathrm{N}$ rate were randomly selected and destructively harvested on 7 May 2013 and the remaining plants were continually treated with the same $\mathrm{N}$ rate treatments from $\mathrm{NH}_{4} \mathrm{NO}_{3}$ until Sept. 2013.

During the 2013 growing season, number of inflorescences, inflorescence stem length, plant height, and leaf SPAD reading (SPAD502; Minolta Camera Co., Japan, one of the first two fully expended leaves was selected to measure SPAD reading) data were collected. During harvesting on 7 May 2013, plant height and number of fans were recorded. Each plant was divided into leaves, roots, and rhizomes. All samples were oven dried at $60^{\circ} \mathrm{C}$ until constant weight and DWs were recorded by tissue type. All samples were ground to pass a 40-mesh sieve using a Wiley Mill (Thomas Scientific, Swedesboro, NJ). 
Total $\mathrm{N}$ was determined using an elemental $\mathrm{C} / \mathrm{N}$ analyzer (Carlo Erba, Milan, Italy). Isotopic ${ }^{15} \mathrm{~N}$ atom percent was determined using an elemental $\mathrm{C} / \mathrm{N}$ analyzer coupled to an Isoprime mass spectrometer (Micromass, Beberly, MA). NDFF for each sampled plant tissue was calculated as follows:

$$
\begin{aligned}
\mathrm{NDFF} \%=[ & \left(\%{ }^{15} \mathrm{~N} \text { sample }-\%^{15} \mathrm{~N} \text { control }\right) / \\
& \left.\left(\%{ }^{15} \mathrm{~N} \text { fertilizer }-\%{ }^{15} \mathrm{~N} \text { natural abundance }\right)\right] \\
& \times 100
\end{aligned}
$$

Natural abundance $\%{ }^{15} \mathrm{~N}$ is considered equal to 0.3665 atom percent; $\%{ }^{15} \mathrm{~N}$ sample $=$ atom percent ${ }^{15} \mathrm{~N}$ in plant sample; $\%{ }^{15} \mathrm{~N}$ fertilizer $=$ atom percent ${ }^{15} \mathrm{~N}$ in fertilizer applied (two atom percent); the mean abundance of $\%{ }^{15} \mathrm{~N}$ in the control sample $(0 \mathrm{~mm}$ ${ }^{15} \mathrm{~N}$ rate in 2013) is $0.3752,0.3786$, and 0.3742 atom percent for leaves, roots, and rhizomes, respectively.

The $\mathrm{N}$ content of each structure was calculated by multiplying the DW by its $\mathrm{N}$ concentration. Total plant $\mathrm{N}$ was calculated as the sum of the content in leaves, roots, and rhizomes. Plant $\mathrm{N}$ allocation was calculated

\begin{tabular}{|c|c|c|c|c|c|c|}
\hline \multirow[b]{2}{*}{$\mathrm{N}$ rates $(\mathrm{mM})$} & \multicolumn{3}{|c|}{ Plant ht $(\mathrm{cm})$} & \multicolumn{2}{|c|}{ SPAD reading } & \multirow{2}{*}{$\frac{\text { Rhizomes/plant (no.) }}{\text { May }}$} \\
\hline & March & April & May & April & May & \\
\hline 0 & 6.1 & 48.3 & 48.4 & 64.2 & 55.3 & 6.2 \\
\hline 5 & 6.1 & 49.8 & 55.6 & 63.5 & 59.7 & 8.2 \\
\hline 10 & 6.1 & 53.1 & 62.7 & 70.5 & 57.8 & 9.4 \\
\hline 15 & 6.1 & 55.0 & 63.8 & 69.5 & 59.1 & 10.6 \\
\hline 20 & 6.1 & 57.8 & 66.3 & 70.2 & 61.7 & 10.2 \\
\hline \multicolumn{7}{|l|}{ Contrasts ${ }^{z}$} \\
\hline $\mathrm{L}$ & NS & NS & $* * * *$ & NS & NS & ** \\
\hline Q & NS & NS & NS & NS & NS & NS \\
\hline
\end{tabular}

Table 1. Plant height, leaf SPAD reading, and number of rhizomes (with diameter $>1 \mathrm{~cm}$ ) in 2013 of container-grown 'Immortality' tall bearded iris fertigated with five different nitrogen $(\mathrm{N})$ rates

${ }^{\mathrm{z}}$ Significant linear (L) or quadratic $(\mathrm{Q})$ contrasts at not significant (NS) or $P \leq 0.05(*), 0.01(* *), 0.001$ $(* * *), 0.0001(* * * *)$ across different $\mathrm{N}$ rates.

\begin{tabular}{|c|c|c|c|c|c|c|c|c|c|c|c|}
\hline \multirow[b]{2}{*}{$\mathrm{N}$ rates $(\mathrm{mM})$} & \multicolumn{4}{|c|}{ DW (g) } & \multicolumn{3}{|c|}{ DW allocation (\%) } & \multicolumn{4}{|c|}{ DW accumulation $(\mathrm{g})$} \\
\hline & Leaf & Root & Rhizome & Total & Leaf & Root & $\overline{\text { Rhizome }}$ & Leaf & Root & Rhizome & Total \\
\hline 0 & 13.9 & 7.9 & 29.5 & 51.4 & 26.9 & 15.6 & 57.5 & 5.2 & 0.6 & 6.0 & 11.8 \\
\hline 5 & 20.2 & 8.8 & 7.8 & 56.8 & 35.6 & 15.7 & 48.7 & 11.4 & 1.5 & 4.3 & 17.2 \\
\hline 10 & 34.2 & 9.1 & 2.7 & 76.0 & 45.1 & 11.9 & 43.0 & 25.5 & 1.8 & 9.2 & 36.4 \\
\hline 15 & 45.1 & 10.3 & 1 & 90.5 & 49.7 & 11.7 & 38.6 & 36.4 & 3 & 11.6 & 51.0 \\
\hline 20 & 40.4 & 9.7 & 36.9 & 87.1 & 46.6 & 11.3 & 42.2 & 31.7 & 2.4 & 13.4 & 47.5 \\
\hline \multicolumn{12}{|l|}{ Contrasts ${ }^{\mathrm{z}}$} \\
\hline $\mathrm{L}$ & $* * * *$ & NS & NS & $* * * *$ & $* * * *$ & $* * * *$ & $* * * *$ & $* * * *$ & NS & NS & $* * * *$ \\
\hline Q & * & NS & NS & NS & $* * * *$ & NS & $* * * *$ & * & NS & NS & NS \\
\hline
\end{tabular}

Table 2. Plant dry weight (DW), DW allocation, and DW accumulation in May 2013 of container-grown 'Immortality' tall bearded iris fertigated with five different nitrogen $(\mathrm{N})$ rates.

${ }^{\mathrm{z}}$ Significant linear (L) or quadratic (Q) contrasts at not significant (NS) or $P \leq 0.05(*), 0.01(* *), 0.001$ $(* * *), 0.0001(* * *)$ across different $\mathrm{N}$ rates. procedure of SAS (version 9.3; SAS Institute, Cary, NC) and count data were analyzed using generalized linear mixed models with the GLIMMIX procedure of SAS.

Differences in plant height, number of fans, DW, and DW allocation in tissues, $\mathrm{N}$ concentration, content, and allocation among various rates of $2013 \mathrm{~N}$ application were compared using polynomial contrasts at $\alpha=$ 0.05 . Effects of $\mathrm{N}$ rates on NupE, $\mathrm{N}_{\mathrm{a}} \mathrm{UE}$, and NUE, and relation between DW and total N content were determined through linear regression analysis. Regression curves were fit to original data and the means were plotted to avoid cluttered figures. Nitrogen and $\mathrm{C}$ concentrations in tissues were considered as covariates in an analysis of $\mathrm{C} / \mathrm{N}$ ratio to evaluate the contribution of $\mathrm{N}$ and $\mathrm{C}$ concentrations to variance in $\mathrm{C} / \mathrm{N}$ ratio. Eta-squared $\left[\eta^{2}=\left(\mathrm{SS}_{\text {effect }} / \mathrm{SS}_{\text {total }}\right)\right]$ was used to assess the proportion of total variance attributable to covariates.

\section{Results and Discussion}

Plant height, leaf SPAD reading, and flowering. Plant height increased as the season progressed in 2013 (Table 1). From March to April, plant height increased $\approx 40 \mathrm{~cm}$ and there was no difference in plant height among different $\mathrm{N}$ rates, which confirms TB iris produce great amount of leaf growth in spring. In May, increasing $\mathrm{N}$ rate

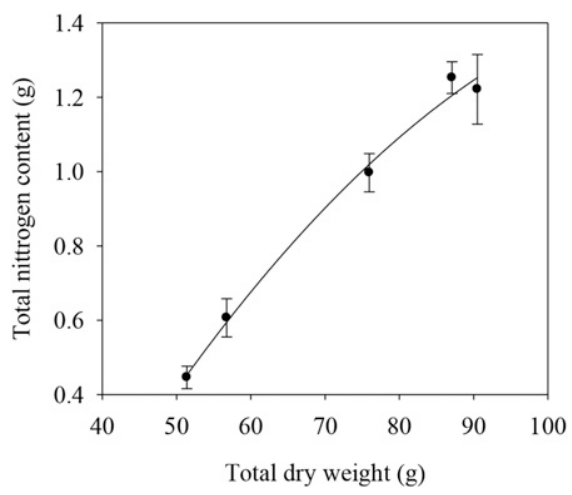

Fig. 1. Total nitrogen $(\mathrm{N})$ content in relation to total dry weight (DW) of container-grown "Immortality" tall bearded iris fertigated with five different $\mathrm{N}$ rates. Each point is mean $\pm \mathrm{SE}$ of five replicates. Regression equations of total $\mathrm{N}$ content and total DW: $y=0.019 x-0.0002 x^{2}, r^{2}=0.9$.

\begin{tabular}{|c|c|c|c|c|c|c|c|c|c|c|c|c|c|}
\hline \multirow[b]{2}{*}{$\mathrm{N}$ rates $(\mathrm{mM})$} & \multicolumn{3}{|c|}{ Concn $(\%)$} & \multicolumn{4}{|c|}{ Content $(\mathrm{g})$} & \multicolumn{3}{|c|}{ Allocation (\%) } & \multicolumn{3}{|c|}{$\mathrm{C} / \mathrm{N}$ ratio } \\
\hline & Leaf & Root & Rhizome & Leaf & Root & Rhizome & Total & $\overline{\text { Leaf }}$ & Root & $\overline{\text { Rhizome }}$ & Leaf & Root & Rhizome \\
\hline 5 & 1.44 & 0.64 & 0.71 & 0.34 & 0.06 & 0.21 & 0.61 & 56.1 & 9.8 & 34.1 & 31.2 & 76.8 & 69.1 \\
\hline 20 & 1.76 & 0.71 & 0.97 & 0.78 & 0.07 & 0.4 & 1.25 & 62.7 & 5.5 & 31.8 & 25.9 & 70.3 & 51.0 \\
\hline \multicolumn{14}{|l|}{ Contrasts $^{\mathrm{z}}$} \\
\hline $\mathrm{L}$ & $* * * *$ & NS & $* * * *$ & $*$ & * & ** & ** & $* * * *$ & $* * *$ & $* * * *$ & $* * * *$ & $* * * *$ & $* * * *$ \\
\hline
\end{tabular}

Table 3. Nitrogen $(\mathrm{N})$ concentration, content, allocation, and carbon/nitrogen $(\mathrm{C} / \mathrm{N})$ ratio in tissues in May 2013 of container-grown 'Immortality' tall bearded iris fertigated with five different $\mathrm{N}$ rates.

${ }^{\mathrm{z}}$ Significant linear $(\mathrm{L})$ or quadratic $(\mathrm{Q})$ contrasts at not significant (NS) or $P \leq 0.05(*), 0.01(* *), 0.001(* * *), 0.0001(* * * *)$ across different $\mathrm{N}$ rates. 
increased plant height linearly. In April and May, leaf SPAD reading was unaffected by $\mathrm{N}$ rate. In many species, leaf SPAD reading has a strong correlation with leaf chlorophyll content, which influences photosynthesis ability of plants (Islam et al., 2009; Wang et al., 2004, 2005).

Spring flowering of 'Immortality' iris occurred from late April to middle May. Flowering performance, including number of inflorescence stems and inflorescence stem length, were unaffected by $\mathrm{N}$ rate (data not shown). In May, number of rhizomes increased with increasing $\mathrm{N}$ rate (Table 1), but diameter and length of rhizomes was unaffected by $\mathrm{N}$ rate (data not shown).

$D W$ and $D W$ allocation. Greater $\mathrm{N}$ rates increased leaf and total plant DW in May 2013, but did not affect root and rhizome DW (Table 2). Between March and May 2013, DW accumulation in leaves increased as $\mathrm{N}$ increased from 5 to $15 \mathrm{~mm}$. Plants receiving higher $\mathrm{N}$ rates allocated a greater proportion of plant DW to leaves, which indicates increasing $\mathrm{N}$ rate promoted more leaf growth than root and rhizome growth. Plants receiving lower $\mathrm{N}$ rates had a higher proportion of total plant DW allocated to roots and rhizomes. This is consistent with other research that plants tend to allocate more biomass to the root system to maximize nutrient uptake when limited nutrients are available (Bi et al., 2007; Dong et al., 2004; Scagel et al., 2011).

$N$ concentration, content, and allocation in different tissues. Increasing $\mathrm{N}$ rate linearly increased $\mathrm{N}$ concentration in both leaves and rhizomes, but did not affect $\mathrm{N}$ concentration in roots (Table 3 ). The $\mathrm{N}$ content in leaves, roots, and total $\mathrm{N}$ was quadratically related to $\mathrm{N}$ rate, whereas a linear relationship best explained $\mathrm{N}$ content in rhizomes. With increasing $\mathrm{N}$ rate, the $\mathrm{N}$ allocated to leaves increased and $\mathrm{N}$ allocated to roots and rhizomes decreased. Photosynthetic capacity is influenced by $\mathrm{N}$ content, as $\mathrm{N}$ is needed to form key proteins in photosynthesis, RuBP carboxylase, and thylakoid proteins (Evans, 1989). The increasing $\mathrm{N}$ content in leaves may indicate more active photosynthesis happened in higher $\mathrm{N}$ rate treatments.

Nitrogen allocation trend was similar to the DW allocation to different tissues. The close correlation between $\mathrm{N}$ content and DW $\left(r^{2}=0.9\right.$, Fig. 1) demonstrates the increasing $\mathrm{N}$ content is related to increasing DW. Increasing $\mathrm{N}$ rate generally increased plant DW, and vigorous growth in turn had an impact on $\mathrm{N}$ uptake. In general, a greater portion of $\mathrm{N}$ was allocated to leaves across the different $\mathrm{N}$ rates, indicating leaves were the major $\mathrm{N}$ sink in May.

$C / N$ ratio. In general, $\mathrm{C} / \mathrm{N}$ ratios in all tissues decreased with increasing $\mathrm{N}$ rate (Table 3). $\mathrm{C} / \mathrm{N}$ ratios ranked in the order of root $>$ rhizome $>$ leaf, which is contrary to the order of $\mathrm{N}$ concentration. Nitrogen concentration in leaves, roots, and rhizomes increased 1.3-, 1.5-, and 1.7-fold, respectively, as $\mathrm{N}$ rate increased from 0 to $20 \mathrm{~mm}$, while $\mathrm{C}$ concentration was much less affected by increasing $\mathrm{N}$ rate. The decline in $\mathrm{C} / \mathrm{N}$ ratio was more affected by increasing $\mathrm{N}$ concentration which was related to $\mathrm{N}$ rate. Nitrogen rates explained $79 \%, 83 \%$, and $66 \%$ of variation in $\mathrm{C} / \mathrm{N}$ ratio in leaves, roots, and rhizomes, respectively (data not shown). Etasquared $\left[\eta^{2}=\left(\mathrm{SS}_{\text {effect }} / \mathrm{SS}_{\text {total }}\right)\right]$ was used to assess the proportion of total variance attributable to covariates.

Nitrogen derived from fertilizer. The amount of NDFF in the leaves, roots, rhizomes,
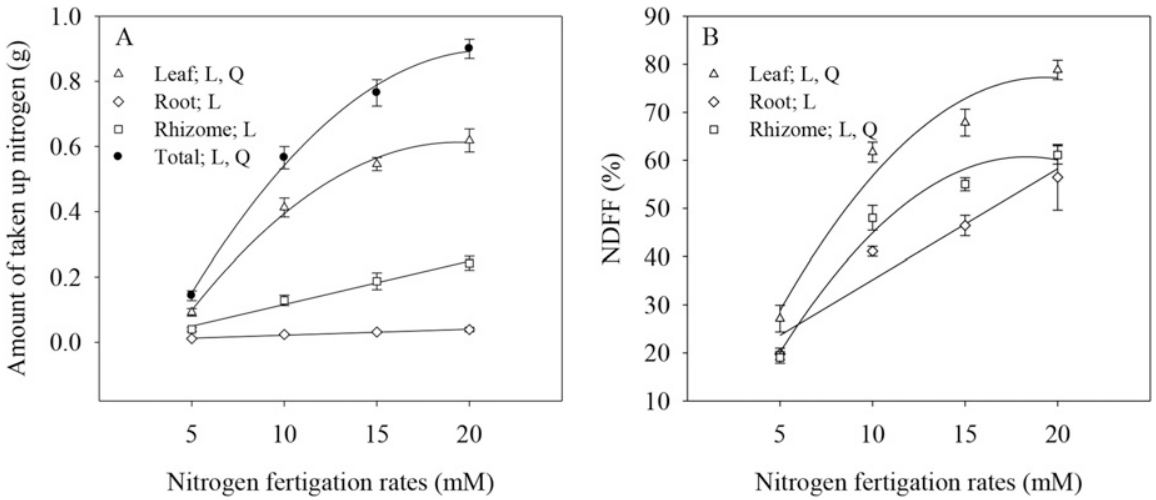

Fig. 2. (A) Amount of taken up nitrogen (N) and (B) proportion of $\mathrm{N}$ derived from the labeled fertilizer (NDFF) in relation to $\mathrm{N}$ fertigation rates of container-grown 'Immortality' tall bearded iris fertigated with different $\mathrm{N}$ rates. Each point is mean \pm SE of five replicates. Regression equations of amount of taken up $\mathrm{N}$ and $\mathrm{N}$ rates: (leaf) $y=0.077+0.034 x-0.0025 x^{2}, r^{2}=0.93$; (root) $y=0.00033 x, r^{2}=0.62$; (rhizome) $y=0.0016 x, r^{2}=0.79$; (total) $y=0.09+0.049 x-0.0063 x^{2}, r^{2}=0.95$. Linear (L); quadratic (Q). Regression equations of NDFF\% and N rates: (leaf) $y=0.0740+0.03225 x-0.0024 x^{2}, r^{2}=0.91$; (root) $y=0.022 x, r^{2}=0.68$; (rhizome) $y=0.072+0.027 x-0.0023 x^{2}, r^{2}=0.93$. Linear (L); quadratic (Q).
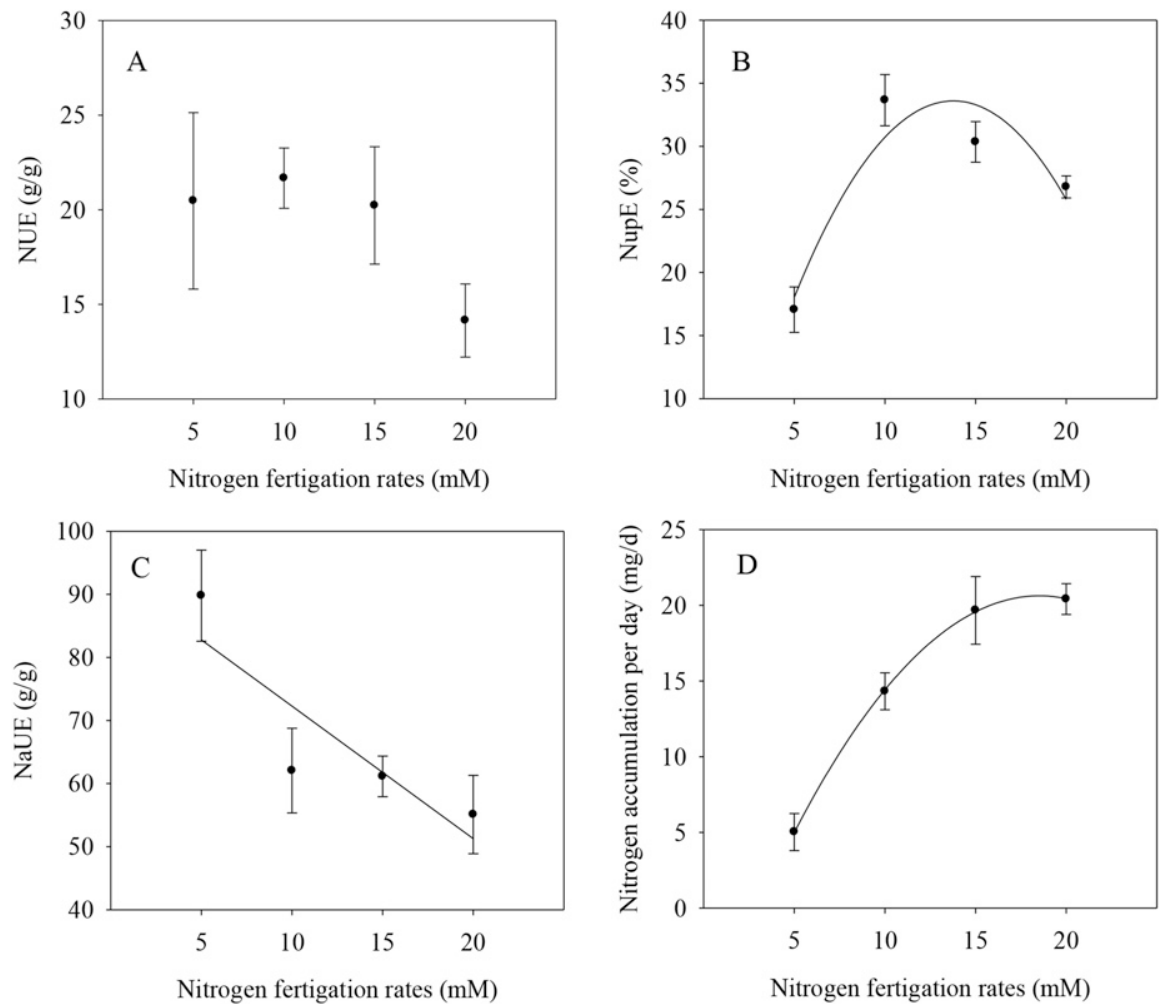

Fig. 3. (A) Nitrogen use efficiency (NUE), (B) nitrogen uptake efficiency (NupE), (C) absorbed nitrogen use efficiency $\left(\mathrm{N}_{\mathrm{a}} \mathrm{UE}\right)$, and (D) nitrogen $(\mathrm{N})$ accumulation per day per plants in relation to $\mathrm{N}$ fertigation rates of container-grown 'Immortality' tall bearded iris fertigated with different $\mathrm{N}$ rates. Each point is mean $\pm \mathrm{SE}$ of five replicates. Regression equation: (NupE) $y=0.063+0.00518 x-0.002 x^{2}, r^{2}=0.68$; $\left(\mathrm{N}_{\mathrm{a}} \mathrm{UE}\right) y=-0.00518 x, r^{2}=0.35$; ( $\mathrm{N}$ accumulation per day) $y=2.67+1.03 x-0.0855 x^{2}, r^{2}=0.8$. 
increasing $\mathrm{N}$ rate, which may lead to more $\mathrm{N}$ runoff into the environment.

In leaves, roots, and rhizomes, the percentage of NDFF increased with increasing $\mathrm{N}$ rate. Percentage of NDFF in leaves was higher than in roots and rhizomes (Fig. 2B). A greater portion of $\mathrm{N}$ taken up from fertilizer was allocated to leaves $(64 \%$ to $73 \%$ ), which suggests leaves were the major sink of spring $\mathrm{N}$ uptake. This is consistent with the results of previous research, which also demonstrated $\mathrm{N}$ uptake in spring preferentially allocated to leaves (Dong et al., 2004; Salaün et al., 2005).

Daily uptake of $\mathrm{N}$ increased from $\approx 5$ to $20 \mathrm{mg} \cdot \mathrm{d}^{-1}$ with increasing $\mathrm{N}$ rate from 5 to $15 \mathrm{~mm}$, and plants receiving $20 \mathrm{~mm} \mathrm{~N}$ had similar daily uptake of $\mathrm{N}$ as those receiving $15 \mathrm{~mm} \mathrm{~N}$ (Fig. 3D). This daily $\mathrm{N}$ uptake amount is helpful to estimate suitable spring $\mathrm{N}$ fertilization rates for growing TB iris.

Nitrogen use efficiency. NUE is defined as the amount of dry matter fixed in plant biomass per unit of $\mathrm{N}$ applied from external sources. In this study, NUE was not statistically different between treatments (Fig. 3A). NUE is not only influenced by the amount of biomass produced by per unit $\mathrm{N}$, but also by the mean residence time of $\mathrm{N}$ in the plant. Thus, NupE can better indicate plants' responses to nutrient availability gradients than NUE (Iversen et al., 2010).

Nitrogen uptake efficiency. In this study, the relationship between NupE and $\mathrm{N}$ rate was best described using a quadratic model (Fig. 3B). When $\mathrm{N}$ rate increased from 5 to $10 \mathrm{~mm}$, the NupE increased from $17.1 \%$ to $33.7 \%$ and then decreased to $26.8 \%$ as $\mathrm{N}$ rate increased from 10 to $20 \mathrm{~mm}$. The NupE was highest in plants treated with $10 \mathrm{~mm}$ ( $\approx 33.7 \%$ ). This indicates $\mathrm{N}$ uptake did not increase commensurate with increased $\mathrm{N}$ availability (Iversen et al., 2010). To increase NupE and reduce $\mathrm{N}$ runoff to the environment, $10 \mathrm{~mm}$ (140 ppm) N fertilizer may be considered most appropriate for spring fertilization in TB iris.

Absorbed nitrogen use efficiency. In this study, $\mathrm{N}_{\mathrm{a}} \mathrm{UE}$ was negatively related to $\mathrm{N}$ rate, which was highest in plants receiving $5 \mathrm{~mm} \mathrm{~N}$ and decreased as $\mathrm{N}$ rate increased from 5 to $20 \mathrm{~mm}$ (Fig. 3C). The decreasing trend of $\mathrm{N}_{\mathrm{a}} \mathrm{UE}$ indicates the amount of DW produced by a certain amount of absorbed $\mathrm{N}$ decreased with increasing $\mathrm{N}$ rate. Considering $\mathrm{N}$ concentration in rhizomes was significantly increased by increasing $\mathrm{N}$ rate, the extra $\mathrm{N}$ may be stored in the rhizomes instead of being used to produce biomass which could lead to a decrease in $\mathrm{N}_{\mathrm{a}} \mathrm{UE}$.

\section{Conclusions}

In summary, plant height, total plant DW, and a plant $\mathrm{N}$ content increased with increasing $\mathrm{N}$ rate. In leaves, roots, and rhizomes, the amount of NDFF increased with increasing $\mathrm{N}$ rate. Leaves were the major sink for NDFF. The $\mathrm{C} / \mathrm{N}$ ratio of leaves, roots, and rhizomes decreased with increasing $\mathrm{N}$ rate as a result of the $\mathrm{N}$ rate's influence on $\mathrm{N}$ concentration in plant tissues. NUE was unaffected by $\mathrm{N}$ rate; $\mathrm{N}_{\mathrm{a}} \mathrm{UE}$ decreased with increasing $\mathrm{N}$ rate. NupE was related to $\mathrm{N}$ rate in a quadratic manner and was highest at the $10 \mathrm{~mm} \mathrm{~N}$ rate, suggesting $10 \mathrm{~mm} \mathrm{~N}$ might be the optimal for improving NupE.

\section{Literature Cited}

Agren, G.I. 2008. Stoichiometry and nutrition of plant growth in natural communities. Annu. Rev. Ecol. Evol. Syst. 39:153-170.

Andersen, P.C., F.M. Rhoads, S.M. Olsen, and K.D. Hill. 1999. Carbon and nitrogen budgets in spring and fall tomato crops. HortScience 34:648-652.

Benincasa, P., M. Guiducci, and F. Tei. 2011. The nitrogen use efficiency: Meaning and sources of variation-case studies on three vegetable crops in central Italy. HortTechnology 21:266-273.

Bi, G., C.F. Scagel, L.H. Fuchigami, and R.P. Regan. 2007. Rate of nitrogen application during the growing season alters the response of container-grown rhododendron and azalea to foliar application of urea in the autumn. J. Hort. Sci. Biotechnol. 82:753-763.

Bi, G., C.F. Scagel, and R.L. Harkess. 2008. Rate of nitrogen fertigation during vegetative growth and spray applications of urea in the fall alters growth and flowering of florists' hydrangeas. HortScience 43:472-477.

Cheng, L. and G. Xia. 2004. Growth and fruiting of young 'Concord' grapevines in relation to reserve nitrogen and carbohydrates. J. Amer. Soc. Hort. Sci. 129:660-666.

Coruzzi, G.M. and L. Zhou. 2001. Carbon and nitrogen sensing and signaling in plants: Emerging 'matrix effects'. Curr. Opin. Plant Biol. 4:247-253.

Dong, S., L. Cheng, C.F. Scagel, and L.H. Fuchigami. 2004. Nitrogen mobilization, nitrogen uptake and growth of cuttings obtained from poplar stock plants grown in different $\mathrm{N}$ regimes and sprayed with urea in autumn. Tree Physiol. 24:355-359.

Evans, J.R. 1989. Photosynthesis and nitrogen relationships in leaves of $\mathrm{C}_{3}$ plants. Oecologia 78:9-19.
Herms, D.A. and W.J. Mattson. 1992. The dilemma of plants: To grow or defend. Qrtly. Rev. Biol. 67:283-335.

Hoagland, D.R. and D.I. Arnon. 1950. The waterculture method for growing plants without soil. Calif. Agr. Expt. Sta. Circ. 347:1-32.

Islam, M.S., M.S.U. Bhuiya, S. Rahman, and M.M. Hussain. 2009. Evaluation of SPAD and LCC based nitrogen management in rice (Oryza sativa L.). Bangladesh J. Agr. Res. 34:661-672.

Iversen, C.M., S.D. Bridgham, and L.E. Kellogg. 2010. Scaling plant nitrogen use and uptake efficiencies in response to nutrient addition in peatlands. Ecology 91:693-707.

Lea-Cox, J.D., J.P. Syvertsen, and D.A. Graetz. 2001. Springtime ${ }^{15}$ nitrogen uptake, partitioning, and leaching losses from young bearing citrus trees of differing nitrogen status. J. Amer. Soc. Hort. Sci. 126:242-251.

Lockatell, M. and G. Don Spoon. 2011. Culturally speaking: The secret of reblooming irises. Bul. Amer. Iris Soc. 92(3):32-33.

Marschner, P. 2012. Mineral nutrition of higher plants. 3rd ed. Academic Press, San Diego, CA.

Niu, G., D. Rodriguez, and M. Gu. 2011. Response of Sophora secundiflora to nitrogen form and rate. HortScience 46:1303-1307.

Righetti, T., D.R. Sandrock, B. Strik, and A. Azarenko. 2007. Appropriate analysis and interpretation approaches to determine fertilizer-derived nitrogen in plant tissues. HortScience 132:429-436.

Salaün, M., V. Guérin, L. Huché-Thélier, S. Charpentier, and F.L. Dily. 2005. Nitrogen storage and mobilization for spring growth in Ligustrum cultivated in container. Sci. Hort. 103:461-471.

Scagel, C.F., G. Bi, L.H. Fuchigami, and R.P. Regan. 2008. Nitrogen availability alters mineral nutrient uptake and demand in container-grown deciduous and evergreen Rhododendron. J. Environ. Hort. 26:177-187.

Scagel, C.F., G. Bi, L.H. Fuchigami, and R.P. Regan. 2011. Effects of irrigation frequency and nitrogen fertilizer rate on water stress, nitrogen uptake, and plant growth of container-grown Rhododendron. HortScience 46:1598-1603.

Scagel, C.F., G. Bi, L.H. Fuchigami, and R.P. Regan. 2012. Irrigation frequency alters nutrient uptake in container-grown Rhododendron with different rates of nitrogen. HortScience 47:189-197.

Syvertsen, J.P. and M.L. Smith. 1996. Nitrogen uptake efficiency and leaching losses from lysimeter-grown Citrus trees fertilized at three nitrogen rates. J. Amer. Hort. Sci. 121:57-62.

Wang, Q., J. Chen, and Y. Li. 2004. Nondestructive and rapid estimation of leaf chlorophyll and nitrogen status of peace lily using a chlorophyll meter. J. Plant Nutr. 27:557-569.

Wang, Q., J. Chen, R.H. Stamps, and Y. Li. 2005. Correlation of visual quality grading and SPAD reading of green-leaved foliage plants. J. Plant Nutr. 28:1215-1225.

Zhang, Z.L. 2009. Carbon and nitrogen nutrient balance signaling in plants. Plant Signal Behav. 4:584-591. 